\title{
Unexpected Discovery of More Elements from the Prehistoric Immature Skeleton from Baousso da Torre (Bausu da Ture) (Liguria, Italy). Inventory, Age-at-Death Estimation, and Probable Sex Assessment of BT3
}

\author{
Découverte inattendue d'éléments supplémentaires du squelette préhistorique immature \\ de Baousso da Torre (Bausu da Ture) (Ligurie, Italie). Inventaire, estimation de l'âge-au-décès \\ et détermination probable du sexe de BT3
}

\author{
S. Villotte \\ Received: 22 March 2018; Accepted: 13 April 2018 \\ (C) Société d'Anthropologie de Paris et Lavoisier SAS 2018
}

\begin{abstract}
This note presents the unexpected discovery of human remains belonging to the immature skeleton from Baousso da Torre (BT3), considered to date from the Gravettian period. These remains were explicitly described as missing by Rivière who undertook the study of this skeleton and was supposedly present at the time of the discovery. These remains, some of them indisputably refitting with the partial skeleton of BT3, permit a better estimation of the age-at-death and a probable assessment of the sex of this individual.
\end{abstract}

Keywords Gravettian · Rediscovery · Old excavations · Immature

Résumé Cette note présente la découverte inattendue de vestiges humains attribuables au squelette immature de Baousso da Torre (BT3), considéré comme datant de la période gravettienne. Ces vestiges étaient explicitement décrits comme manquants par Rivière, considéré jusqu'à présent comme l'inventeur de restes squelettiques et également auteur de la première description du matériel. Ces vestiges, dont certains remontent indiscutablement avec le squelette partiel de BT3, permettent de préciser l'âge au décès et le sexe de cet individu.

Mots clés Gravettien · Redécouverte · Anciennes fouilles · Immature

S. Villotte $(\square)$

CNRS, UMR 5199 PACEA, UMR 5199 PACEA,

Université de Bordeaux - CNRS

Bât B8, allée Geoffroy Saint Hilaire,

CS 50023, 33615 Pessac CEDEX France

e-mail : sebastien.villotte@u-bordeaux.fr

\section{Introduction}

In 1873, Rivière discovered three single prehistoric burials at Baousso da Torre (Liguria, Italy). The Baousso da Torre cave (also called Bausu da Ture) is part of the Balzi Rossi (also called Grimaldi) complex of caves and rock shelters, one of the most important European Paleolithic site complexes on the Mediterranean coast, on the border between Italy and France [1]. BT1, a male who died before 50 years of age, was found in February 1873, whereas the skeletons of BT2 (a male who died in his third decade) and BT3 (an immature individual) were discovered in June of the same year [2-4]. BT1 and BT3 were subsequently lost and re-discovered in 2008 by Henry-Gambier in the collections of the Musée lorrain [3]. Several attempts to obtain direct and indirect radiocarbon dates for these individuals failed $[3,4]$, but the archaeological context indicates that an Upper Paleolithic date is secure and that a Gravettian date is probable [5-8]. The comprehensive descriptive and comparative study of the two adults was published recently [4]. This note focuses on the third individual, BT3.

\section{BT3 skeleton as it was described by Rivière and rediscovered by Henry-Gambier}

BT3 was stratigraphically slightly above BT2, and buried in a ventral decubitus position (i.e. prone, a rare position for the Gravettian [5]), without ochre or associated goods. Apparently, the BT3 skeleton was badly preserved at the time of the discovery: "C'est le 3 juin 1873 que nous avons commencé à découvrir, à $3 m$, 90 de profondeur au-dessous de la surface du sol, le second squelette d'adulte de la sixième 
caverne et, deux jours plus tard, quelques os brisés provenant d'un enfant dont nous parlerons plus loin." [2, p. 219]. Rivière was an archeologist but also a physician. His descriptions of burials and human remains from the Balzi Rossi are usually quite lengthy and seem accurate, but he was notably briefer in the case of BT3, likely due to the relatively poor preservation of the skeleton and, maybe, the age of the individual (which may have made it of less interest in terms of morphological comparisons). Nevertheless, Rivière specified the state of preservation of each bone and gave the maximum preserved length for most of them [2]. The extremely good match between these data and those obtained from the immature human remains found in the Musée lorrain collection supports a positive identification [3]. Four examples, which will be useful in the following part of this article, are provided to illustrate these similarities.

For the neurocranium, Rivière [2] was extremely clear. He explicitly said that only one roughly quadrangular fragment $(56 \times 58 \mathrm{~mm})$, likely from the right parietal, was preserved. Moreover, he specified that sutures were preserved on two borders, and that the fragment was thin. Only one fragment of immature neurocranium was indeed found in the Musée lorrain collection, and it has exactly these dimensions, morphology, and state of preservation.

For the right femur, Rivière wrote that only the complete distal unfused epiphysis and a very short part of the diaphysis (less than 6 centimeters), lacking the greater trochanter and the head, were found [2]. Three fragments of a right immature femur were found in the Musée lorain collection, two of them fit this description perfectly, the third one being the unfused femoral head [3].

Rivière described the left patella (well preserved with slight damage to the inferior part) but did not mention the right one [2]. Only one left immature patella was found in the Musée lorrain collection.

For the right talus, Rivière explicitly mentioned that only the anterior part was preserved [2], and indeed that is what was found in the Musée lorain.

\section{Unexpected new discoveries}

Except for a few minor discrepancies, the skeletal elements described by Rivière in 1887 as belonging to BT3 match those found in the Musée lorrain, and only a few more immature bones not described by Rivière were found in these collections. Thus, until July 2012, most of the history of the BT3 remains was apparently clear [3]:

- The remains were excavated by Rivière in June 1873, who published the description of all the bones in 1887 .

- The skeleton stayed in Rivière's collection until his death in 1922 .
- This collection was then auctioned at the "Hotel Drouot" in Paris, and a part of it, including the BT3 skeleton, was bought by Goury (1877-1959), a prehistorian, and curator of the Musée lorrain from 1920 to 1927.

- Goury donated his collection to the museum in 1955 and the skeletal remains of BT3 remained there until their rediscovery by Henry-Gambier in 2008.

In 2012, on the advice of Henry-Gambier, the author had a brief look at some bones curated at the Institut de paléontologie humaine (IPH) in Paris. These bones are labeled in the IPH database as "Baoussé Roussé (entrée 1968-69)", and "Menton (entrée 1972)". As this database contains 79 entries with these labels, whereas 102 specimens were identified, the author subsequently created a new coding system and gave the IPH curators an excel sheet with their exact descriptions and the relationships between the labeling systems. A minimum number of six individuals was determined (based on the left humerus) but taking into account the varied preservation and morphologies (some bones are likely not Pleistocene) of the remains, a greater number of individuals is suspected. At least one of these bones belongs to the BT2 skeleton (a first thoracic vertebra [4]), and some others may belong to BT1 or BT2. More importantly, two sets of immature bones were identified. The first one comprises 20 fragments of the neurocranium (most of them being unidentified precisely at that time) and the second set is composed of 19 infracranial remains (Table 1). There is no duplication in the infracranial assemblage (the same seems true for the neurocranium, but this needs to be carefully checked at a future date). All the infracranial bones have the same color (greyish), robusticity (or lack of robusticity) and stage of maturation, and most of the cranial and infracranial remains are partly covered by a very thin layer of concretion. As the author was studying the human material from Baousso da Torre at that time, the striking morphological similarities, taphonomic alterations and color between these bones and those from BT3 were obvious. In October 2013, this initial impression was confirmed by bringing four fragments of bone from the Musée lorrain collection to the IPH. The result is illustrated by the figure 1 . The association of fragments from both collections is unquestionable, and it seems highly probable that, at least for the infracranial remains, all of the selected bones belong to BT3. For the cranial remains, some refits have been found (at least two fragments with the quadrangular fragment of parietal) but more time needs to be spent to carefully analyze these remains (Table 1, Figure 1).

\section{Some remarks on the paleobiology of BT3}

This discovery significantly increases the representation of the BT3 skeleton (Table 2). When data from both collections 


\begin{tabular}{|c|c|c|c|c|c|c|}
\hline Villotte Labels & $\begin{array}{l}\text { IPH labels } \\
\text { (database) }\end{array}$ & "Site" & Drawer & $\begin{array}{l}\mathrm{N}^{\circ} \\
\text { on the bone }\end{array}$ & Bone & Preservation \\
\hline BRIPH68-022 & $1968-9-25$ & Baoussé Roussé & 23 & $1968-9-25$ & Thoracic vertebra & Posterior part \\
\hline BRIPH68-023 & $1968-9-27$ & Baoussé Roussé & 23 & $1968-9-27$ & Lumbar vertebra & $\begin{array}{l}\text { Right lamina } \\
\text { and articular process }\end{array}$ \\
\hline BRIPH68-024 & $1968-9$ & Baoussé Roussé & 22 & $1968-9$ & Right humerus & $\begin{array}{l}\text { Distal third } \\
\text { of the diaphysis }\end{array}$ \\
\hline BRIPH68-025 & $1968-9-12$ & Baoussé Roussé & 22 & 1968-9-19 & Right radius & Fragment of diaphysis \\
\hline BRIPH68-026 & $1968-9-20$ & Baoussé Roussé & 22 & $1968-9-20$ & Right ulna & Fragment of diaphysis \\
\hline BRIPH68-027 & $1968-9-15$ & Baoussé Roussé & 23 & $1968-9-15$ & Right Ilium & Complete \\
\hline BRIPH68-028 & & Baoussé Roussé & 23 & $1968-9-15$ & Right ischium & Fragmented \\
\hline BRIPH68-029 & & Baoussé Roussé & 23 & $1968-9-15$ & Left ischium & Subcomplete \\
\hline BRIPH68-030 & $1968-9-21$ & Baoussé Roussé & 23 & $1968-9-21$ & Right patella & Complete \\
\hline BRIPH68-031 & $1968-9-28$ & Baoussé Roussé & 23 & $1968-9-28$ & Right (?) tibia & $\begin{array}{l}\text { Medial part } \\
\text { of the proximal epiphysis }\end{array}$ \\
\hline BRIPH68-032 & & Baoussé Roussé & 22 & $1968-9$ & Right femur & $\begin{array}{l}\text { Proximal third } \\
\text { of the diaphysis }\end{array}$ \\
\hline BRIPH68-033 & $1968-9-17$ & Baoussé Roussé & 22 & $1968-9-17$ & Left tibia & $\begin{array}{l}\text { Proximal third } \\
\text { of the diaphysis }\end{array}$ \\
\hline BRIPH68-034 & & Baoussé Roussé & 23 & $1968-9-16$ & Left fibula & $\begin{array}{l}\text { distal extremity } \\
\text { of the diaphysis }\end{array}$ \\
\hline BRIPH68-035 & 1968-9-18 & Baoussé Roussé & 23 & $1968-9-18$ & Left (?) fibula & Fragment of diaphysis \\
\hline BRIPH68-036 & $1968-9-30$ & Baoussé Roussé & 23 & $1968-9-30$ & Right fibula & Distal epiphysis \\
\hline BRIPH68-037 & $1968-9-24$ & Baoussé Roussé & 23 & $1968-9-24$ & Right (?) Fibula & Fragment of diaphysis \\
\hline BRIPH68-038 & $1968-9-40$ & Baoussé Roussé & 23 & $1968-9-40$ & Right talus & Postero lateral portion \\
\hline BRIPH68-039 & $1968-9-44$ & Baoussé Roussé & 23 & $1968-9-44$ & Right cuboïd & complete \\
\hline BRIPH68-040 & $1968-9-47$ & Baoussé Roussé & 23 & $1968-9-47$ & Right metatarsal IV & Proximal end \\
\hline
\end{tabular}

are brought together, they permit an estimate of the most likely age-at-death of the individual, following [9-11], as being between 10 and 14 years (Table 3 ).

Fortunately, this age-range is the best for attempting to assess the sex of an immature individual based on the morphology of the ilium: it has been shown that iliac shape differences between the sexes increases during ontogeny $[12,13]$, and that that shape becomes significantly sexually dimorphic after 11 years of age, although visible shape differences can be observed even earlier [12,14]. A sex assessment for BT3 individual was attempted using the complete right ilium (Fig. 2), even though (and taking into account) sex-assessment of juveniles has been considered as one of the most thorny problems in biological anthropology since the origin of the discipline. Pictures of the bone were taken following recommendations in $[15,16]$, and analyzed with ImageJ. Observations were made according to [16-18]. Schutkowski's and Weaver's methods $[17,18]$ were originally created on neonates and young children, and their accuracy may be fairly low when applied to samples other than those used to create them (e.g. $[19,20])$. However when the results of the methods are displayed by age group, they show relatively good accuracy for individuals (especially males) who died between 10 and 14 years old [21-23]. Luna et al [16] presented clear and well illustrated metrical and non-metrical, morphological methods for recording the juvenile auricular surface [16], something that was previously lacking [24]. The visual recording part was applied to BT3, but unfortunately the measures were not recordable due to the extent of taphonomic alterations of the margin of the auricular surface. Table 4 displays the results obtained. All criteria point toward a male assessment, and the author considers it to be reasonably reliable.

Finally, it is worthwhile noting that at least one fragment of fibula (and maybe two other fragments, one of the frontal bone and of the right ulna) displays pathological changes. This fibula is broken through an abnormal enlargement of the diaphysis, which displays an active sub-periosteal reaction in this area. 


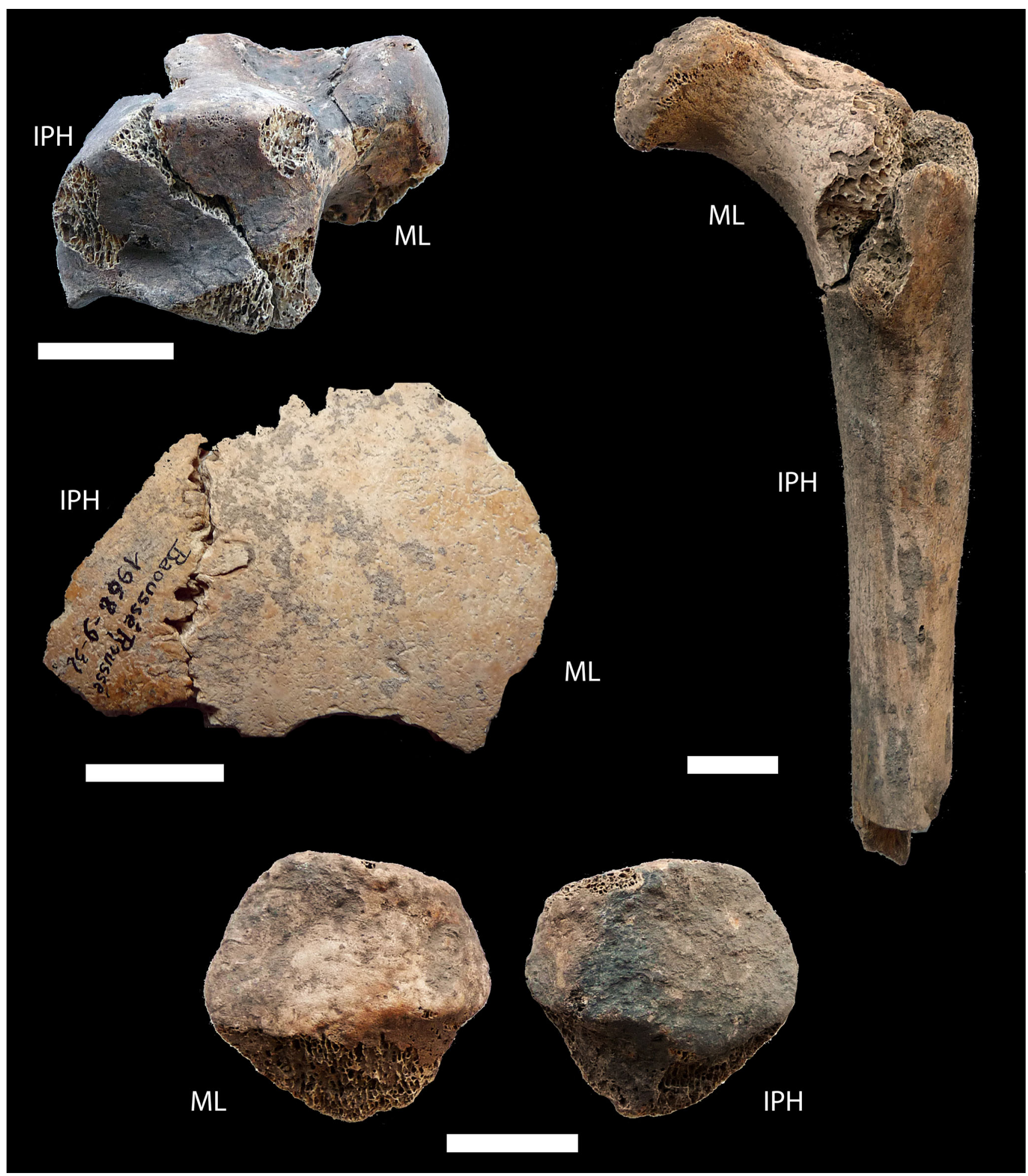

Fig.1 Examples of refitting between fragments from the Musée lorrain (ML) and the IPH collections. Scales $=2 \mathrm{~cm} /$ Exemples de remontages entre des fragments du Musée lorrain $(M L)$ et de l'IPH. Echelles $=2 \mathrm{~cm}$ 
Table 2 The state of preservation of the BT3 remains, reported separately for bones from the right and the left sides, respectively. -: missing; i: intact; d: damaged; f: fragmented; ff: very fragmented / Etat de conservation des restes squelettiques de BT3, pour chaque os du coté droit et gauche respectivement. - : manquant; $i$ : intact; $d$ : endommagé; f: fragmenté; ff: très fragmenté.

Musée lorrain Musée lorrain + IPH

Neurocranium (ff), face (ff), sacrum (ff), humeri (d / -), ulnae (f / -), coxal bones (- / ff), femora (f/d), patellae (- / i), tibiae (- / ff), tali (f / i), calcanei (d / f), other tarsals (1f / 4i-d), metatarsals (2d-f/3i-f), phalanges (3i / 5i-f).
Neurocranium (?), face (ff), vertebrae t. (1f), vertebrae 1. (1f), sacrum (ff), humeri (d/ -), radii (d/ -), ulnae (d/ -), coxal bones (d / f), femora (d / d), patellae (i / i), tibiae (ff / d), fibulae (f / f), tali $(\mathrm{d} / \mathrm{i})$, calcanei $(\mathrm{d} / \mathrm{f})$, other tarsals $(2 \mathrm{i}-\mathrm{f} / 4 \mathrm{i}-\mathrm{d})$, metatarsals (3d-f / 3i-f), phalanges (3i / 5i-f).

Table 3 Age range estimates from each of the observable indicators present in the BT3 skeletal remains / Estimations de classes d'âge pour chacun des indicateurs observables pour le squelette de BT3.

\begin{tabular}{|c|c|c|c|}
\hline Indicator of age-at-death & Collection & Age range & Reference \\
\hline Left upper canine (stage R 3/4 or Rc) & Musée lorrain & $8-16$ y & {$[10]$} \\
\hline Left upper first premolar (erupted) & Musée lorrain & $>10 y$ & {$[10]$} \\
\hline Left upper second premolar (erupted) & Musée lorrain & $>11 \mathrm{y}$ & {$[10]$} \\
\hline Left upper first molar (stage A $1 / 2$ or Ac) & Musée lorrain & $>10 \mathrm{y}$ & {$[10]$} \\
\hline Right humeral head unfused & Musée lorrain & $<20 \mathrm{y}$ & [9] \\
\hline Right humeral medial epicondyle unfused & IPH & $<19$ y & {$[9]$} \\
\hline Right humeral distal end unfused & IPH & $<15 \mathrm{y}$ & [9] \\
\hline Right ulnar proximal end unfused & Musée lorrain & $<16 \mathrm{y}$ & [9] \\
\hline Right and left iliac crests unfused & IPH and Musée lorrain & $<20 y$ & [9] \\
\hline Right ischium ilium unfused & $\mathrm{IPH}$ & $<19$ y & {$[9]$} \\
\hline Right ilium pubis unfused & IPH & $<19$ y & [9] \\
\hline Right anterior inferior iliac spine unfused & IPH & $<16 y$ & [9] \\
\hline Right and left ischial tuberosities unfused & IPH & $<20 \mathrm{y}$ & [9] \\
\hline Left femoral head partially fused (?) & Musée lorrain & $12-24 y$ & [9] \\
\hline Right femoral head unfused & Musée lorrain & $<20 \mathrm{y}$ & {$[9]$} \\
\hline Right and left lesser trochanters unfused & IPH and Musée lorrain & $<20 y$ & [9] \\
\hline Right greater trochanter unfused & $\mathrm{IPH}$ & $<20 y$ & [9] \\
\hline Right and left femur distal ends unfused & Musée lorrain & $<20 \mathrm{y}$ & [9] \\
\hline Left femur maximal length (ca. $416.0 \mathrm{~mm}$ ) including epiphyses & Musée lorrain & $10-13$ y & [9] \\
\hline Left femur diaphyseal length (ca. $380.0 \mathrm{~mm}$ ) & Musée lorrain & $>11 \mathrm{y}$ & [9] \\
\hline Right (?) tibia proximal epiphysis unfused & IPH & $<20 \mathrm{y}$ & [9] \\
\hline Right and left fibula distal epiphyses unfused & IPH & $<20 y$ & [9] \\
\hline Right calcaneus epiphysis unfused & Musée lorrain & $<16 \mathrm{y}$ & [9] \\
\hline $\begin{array}{l}\text { Right calcaneus dimensions (maximum length }=\text { ca. } 72.0 \mathrm{~mm} \text {; } \\
\text { middle breadth }=42.4 \mathrm{~mm} \text { ) }\end{array}$ & Musée lorrain & $14-15 y$ & {$[11]$} \\
\hline
\end{tabular}

\section{Some concluding thoughts}

At least 19 infracranial fragments and two cranial fragments belonging to BT3 were discovered at the IPH. It is likely that many other cranial fragments belong to this individual. The skeletal remains of BT3 have still to be studied in greater detail due to the difficulty of analyzing fragments curated in two different places. However, this discovery permits allocation of BT3 to the age class 10 to 14 years and a likely male sex assessment, as well as the identification of at least one pathological bone.

Gravettian immature individuals are relatively rare [5]. A detailed study of BT3 would thus provide new data on the paleobiology, including ontogenetic aspects, of folks from this time period.

Two "mysteries" still remain: why did Rivière not mention these remains, and how did they come to be in the IPH drawers? At the end of the description of the BT3 skeletal 
remains, Rivière clearly stated that he found no other skeletal elements, apart from a few fragments that could not be identified. It seems he was not referring to the bones curated at the IPH, so one can posit that Rivière did not actually see

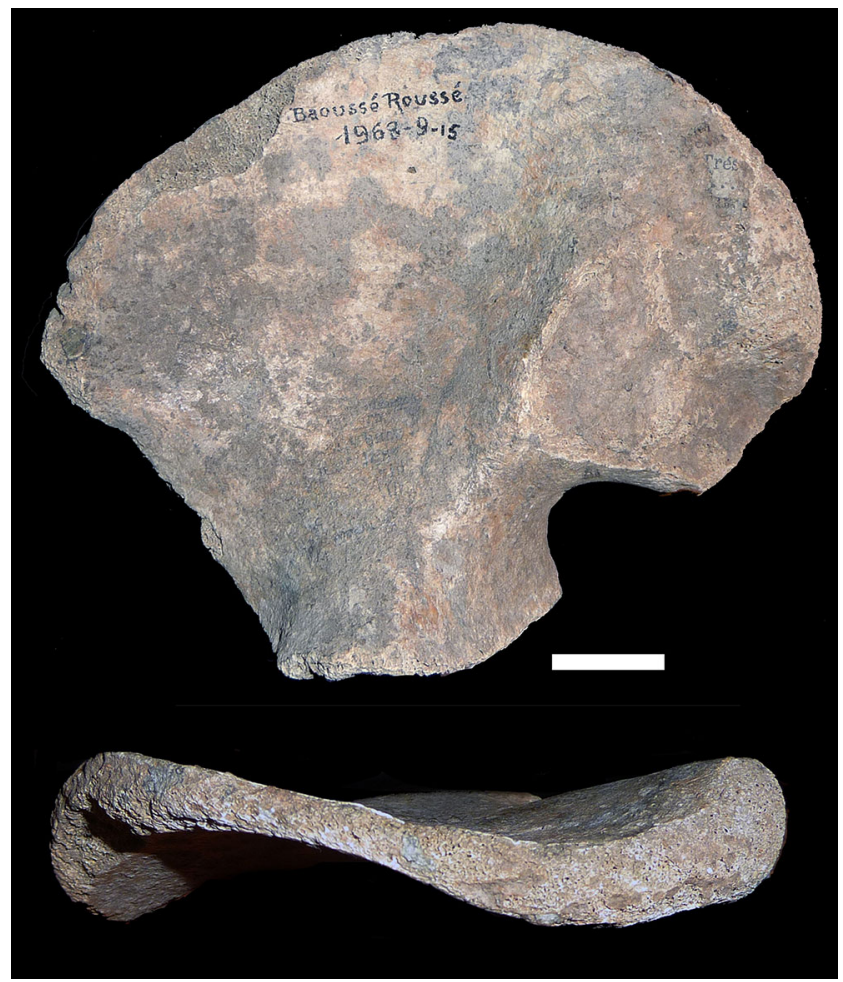

Fig. 2 Medial and superior views of the right ilium. Scale $=2 \mathrm{~cm} /$ Ilium droit, vues médiale et supérieure. Echelle $=2 \mathrm{~cm}$ these remains. Rivière [2] did not clearly state who found the burials, even though he gave the impression that he was there (in his monograph he generally used the term "we" for "I", and did use "we" for BT3 discovery as well). One hypothesis would be that Rivière was not actually present at the time of the discovery and that somebody else excavated the remains. For some unknown reason, some of the bones were removed and not seen by Rivière. This would explain the first mystery. To attempt to resolve the second one, one would have to access to the archives of the IPH and look for some information on the material.

Acknowledgments The author thanks D. Henry-Gambier (UMR 5199 PACEA, Université de Bordeaux - CNRS) for giving him the opportunity to study this fossil, and R. Dagorne and T. Dechezleprêtre (Musée lorrain), Stéphanie Renault (Muséum national d'Histoire naturelle) and Amélie Vialet (Institut de Paléontologie humaine) who allowed access to the material. Thanks to C. Knüsel (UMR 5199 PACEA, Université de Bordeaux - CNRS), E. Trinkaus (Department of Anthropology, Washington University), the editor and the two anonymous reviewers for their useful comments on the manuscript. This research was partially funded by the CNRS, the ANR (ANR GUEROPE (ANR06-CONF-0008); ANR GRAVETT'OS (ANR-15-CE330004)), and the British Academy (BA small grant).

Conflict of interest: Author do not have any conflict of interest to declare.

\begin{tabular}{|c|c|c|c|}
\hline Criterion (reference) & Morphology of BT3 ilium & $\begin{array}{l}\text { Considered } \\
\text { as indicator of: }\end{array}$ & $\begin{array}{l}\text { Test for } 10+\text { years old juvenile } \\
\text { individuals }\end{array}$ \\
\hline Greater sciatic notch angle [17] & $90.9^{\circ}$ (small) & Male & $\begin{array}{l}\text { Never great in males, sometimes } \\
\text { small in females }[21,22]\end{array}$ \\
\hline Greater sciatic notch depth [17] & Deep & Male & $\begin{array}{l}\text { Never shallow in males, sometimes } \\
\text { deep in females }[21,22]\end{array}$ \\
\hline Auricular elevation [18] & Not elevated & Male & $\begin{array}{l}\text { Rarely elevated in males, rarely not } \\
\text { in females }[21,23]\end{array}$ \\
\hline Arch criteria [17] & Bordering auricular surface & Male & $\begin{array}{l}\text { Variation across studies } \\
\text { and observers, likely a poor } \\
\text { indicator }[21,25]\end{array}$ \\
\hline $\begin{array}{l}\text { Auricular surface overall } \\
\text { morphology [16] }\end{array}$ & $\begin{array}{l}\mathrm{V} \text { shape, the inferior edge is slightly } \\
\text { longer than the anterior edge, } \\
\text { and obtuse angle }\end{array}$ & Male & $\begin{array}{l}\text { Configuration frequently seen } \\
\text { in males, rarely in females [16] }\end{array}$ \\
\hline Apex morphology [16] & Angular & Male & $\begin{array}{l}\text { Rarely rounded in males, rarely } \\
\text { angular in females }[16]\end{array}$ \\
\hline Curvature of the iliac crest [17] & Marked S-shape & Male & $\begin{array}{l}\text { Variable in males, Marked S-Shape } \\
\text { rare in females [21] }\end{array}$ \\
\hline
\end{tabular}




\section{References}

1. Formicola V, Holt BM (2015). Tall guys and fat ladies: Grimaldi's Upper Paleolithic burials and figurines in an historical perspective. J Anthropol Sci 93: 71-88.

2. Rivière E (1887). Antiquité de l'homme dans les AlpesMaritimes. J.-B. Baillière, Paris, $337 \mathrm{p}$

3. Villotte S, Henry-Gambier D (2010). The rediscovery of two Upper Palaeolithic skeletons from Baousso da Torre cave (Liguria-Italy). Am J Phys Anthropol 141(1): 3-6.

4. Villotte S, Samsel M, Sparacello V (2017). The paleobiology of two adult skeletons from Baousso da Torre (Bausu da Ture) (Liguria, Italy): Implications for Gravettian lifestyle. CR Palévol 16(4): 462-73.

5. Henry-Gambier D (2008). Comportement des populations d'Europe au Gravettien : Pratiques funéraires et interprétations. Paleo 20: $399-438$.

6. Henry-Gambier D (2001). La sépulture des enfants de Grimaldi (Grotte des Enfants site des Baoussé-Roussé, Italie). Anthropologie et palethnologie funéraire des populations de la fin du Paléolithique supérieur. éditions du CTHS, Paris, $177 \mathrm{p}$

7. Mussi M (2001). Earliest Italy: an overview of the Italian Paleolithic and Mesolithic. Kluwer Academic Publishers, New York, $418 \mathrm{p}$

8. Mussi M (1986). Italian Palaeolithic and Mesolithic Burials. Human Evolution 1(6): 545-546.

9. Schaefer M, Black S, Scheuer L (2009). Juvenile osteology: a laboratory and field manual. Elsevier, Academic Press, Amsterdam, $369 \mathrm{p}$

10. AlQahtani SJ, Hector MP, Liversidge HM (2010). Brief communication: The London atlas of human tooth development and eruption. Am J Phys Anthropol 142(3): 481-490.

11. Passalacqua NV (2013). Subadult Age-at-Death Estimation From the Human Calcaneus. Int J of Osteoarchaeol 23(4): 471-4.

12. Bilfeld MF, Dedouit F, Sans N, et al (2013). Ontogeny of Size and Shape Sexual Dimorphism in the Ilium: A Multislice Computed Tomography Study by Geometric Morphometry. J Forensic Sci 58(2): 303-10.

13. Wilson LAB, Ives R, Cardoso HFV, et al (2015). Shape, size, and maturity trajectories of the human ilium. Am J Phys Anthropol 156(1): 19-34.
14. Wilson LAB, Cardoso HFV, Humphrey LT (2011). On the reliability of a geometric morphometric approach to sex determination: A blind test of six criteria of the juvenile ilium. Forensic Sci Int 206(1): 35-42.

15. Wilson LA, MacLeod N, Humphrey LT (2008). Morphometric Criteria for Sexing Juvenile Human Skeletons Using the Ilium. J Forensic Sci 53(2): 269-78.

16. Luna LH, Aranda CM, Santos AL (2017). New Method for Sex Prediction Using the Human Non-Adult Auricular Surface of the Ilium in the Collection of Identified Skeletons of the University of Coimbra. Int J of Osteoarchaeol 27(5): 898-911.

17. Schutkowski H (1993). Sex determination of infant and juvenile skeletons: I. Morphognostic features. Am J Phys Anthropol 90 (2): 199-205.

18. Weaver DS (1980). Sex differences in the Ilia of a known sex and age sample of fetal and infant Skeletons. Am J Phys Anthropol 52(2): 191-5.

19. Majó T, Tillier A-M, Bruzek J (1993). Test des fonctions discriminantes de Schutkowski impliquant l'ilium pour la détermination du sexe dans des séries d'enfants de sexe et d'âge connus. BMSAP 5(1-2): 61-8.

20. Hunt D (1990). Sex Determination in the Subadult Ilia: An Indirect Test of Weaver's Nonmetric Sexing Method. J Forensic Sci 35(4): 881-5.

21. Sutter RC (2003). Nonmetric subadult skeletal sexing traits: I. A blind test of the accuracy of eight previously proposed methods using prehistoric known-sex mummies from northern Chile. J Forensic Sci 48(5): 827-35.

22. Vlak D, Roksandic M, Schillaci MA (2008). Greater sciatic notch as a sex indicator in juveniles. Am J Phys Anthropol 137(3): 309-15.

23. Mittler DM, Sheridan SG (1992). Sex determination in subadults using auricular surface morphology: a forensic science perspective. J Forensic Sci 37(4): 1068-75.

24. Majó T (1996). Réflexions méthodologiques liées à la diagnose sexuelle des squelettes non-adultes. BMSAP 8(3-4): 481-90.

25. Cardoso HFV, Saunders SR (2008). Two arch criteria of the ilium for sex determination of immature skeletal remains: A test of their accuracy and an assessment of intra- and inter-observer error. Forensic Sci Int 178(1): 24-9. 